\title{
Viljelymenetelmän, lajikkeen ja siemenperunan seittirupisuuden vaikutus perunaseitin (Rhizoctonia solani) määrään
}

\author{
Ahvenniemi PM, Lehtonen MJ, Wilson PS \& Valkonen JPT
}

Soveltavan biologian laitos, PO Box 27, FIN-00014 Helsingin yliopisto

\section{Tiivistelmä}

Siemenen seittirupisuuden (6 tasoa), maaperän ominaisuuksien (monokulttuuri tai luomuviljely) ja lajikkeen (Van Gogh tai Saturna) vaikutusta perunaseitin esiintymiseen tutkittiin vuosina 2003-2005 järjesteyssä kenttäkokeessa. Siemenperunan tautisuuden (seittirupisuuden) lisääntyessä versolaikun määrä kasvoi, varsija mukulaluku pieneni ja sadon määrää ja tärkkelyspitoisuus laski. Myöskin laatu heikkeni, kun vihertyneiden, epämuotoisten ja onttojen mukuloiden osuus sadossa kasvoi. Viljelymenetelmä ei vaikuttanut kovin selvästi seittisyyteen, mutta siemenen seittirupisuuden lisääntyessä seittiruven määrä sadossa lisääntyi ainoastaan luomussa. Van Goghissa oli seittiongelmia hieman enemmän kuin Saturnassa. Erityisesti keskeltä ruskolaikkuisten ja onttojen mukuloiden määrä lisääntyi Van Goghilla selvästi siemenen seittirupisuuden lisääntyessä. Tulokset ovat alustavia ja kattavat kaksi ensimmäistä koevuotta (2003-2004).

\section{Johdanto}

Tässä tutkimuksessa pyrittiin selvittämään siemenperunan mukana tulevan seittitartunnan, perunamaan viljelytaustan ja käytetyn perunalajikkeen vaikutusta perunaseitin määrään. Tarve tämänlaatuiseen tutkimukseen nousi siitä tosiasiasta, että peruna viljellään Suomessa pääasiassa pitkässä monokulttuurissa. Tutkittu tieto tällaisen poikkeuksellisen pitkään jatkuneen yksipuolisen perunanviljelyn vaikutuksesta perunan seittisyyteen puuttuu kuitenkin kokonaan. Toisaalta siemenperunassa on vaihtelevia määriä seittirupea, eikä tämän tartuntalähteen merkitystä ole yksityiskohtaisesti tutkittu pohjoisissa kasvuoloissamme. Esitämme tässä alustavia tuloksia kahdelta ensimmäiseltä tutkimusvuodelta (2003-2004).

\section{Aineisto ja menetelmät}

Tutkimus suoritettiin luomutilalla ja tavanomaista perunanviljelyä pitkässä monokulttuurissa (yli 20 vuotta) harjoittaneilla naapuritiloilla. Luomutilalta koelohkoksi valittiin sellainen perunanviljelyvuorossa ollut lohko, jonka välittömässä läheisyydessä sijaitsi perunan monokulttuuri. Luomutilan koelohkon taustana oli molempina vuosina neljä välikasvia (2003: ohra $+3 \mathrm{x}$ timotei/puna-apila; 2004: $2 \mathrm{x}$ porkkana $+2 \mathrm{x}$ timotei/puna-apila). Koelohkopari oli eri vuosina eri paikassa, noudattaen luomutilan viljelykiertoa. Siemenperunaksi valittiin seittirupinen siemenerä, josta valikoitiin mukuloita viiteen eri seittirupisuusluokkaan, terveistä voimakkaasti seittirupisiin, Dijstin (1985) kehittämän asteikon mukaisesti (Kuvio 1). Sen lisäksi kontrollina käytettiin sertifioitua seittiruvetonta siementä, joka lisäksi pintasteriloitiin natriumhypokloriitilla. Koelajikkeet olivat yleisimmät ruokaperuna- ja tärkkelyslajikkeet Van Gogh ja Saturna.

Kuvio 1. Siemenen seittirupisuuden määrittäminen: $0=$ serittiruveton, $1=$ hyvin lievä, $2=$ lievä, $3=$ kohtalainen, $4=$ voimakas (Dijst 1985).

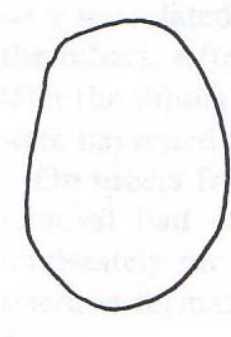

0
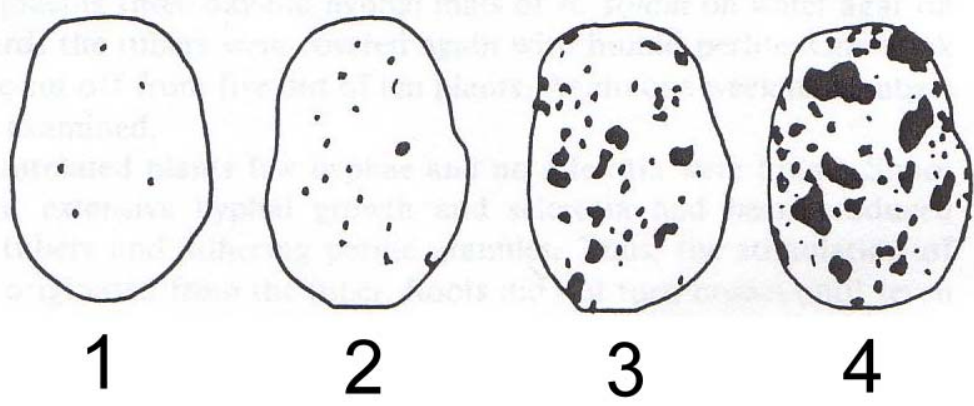

Dijstin (1985) seittirupisuusasteikkoa käytettiin myös sadon seittirupisuuden määrittämiseen. Versolaikun määrä kasvustossa (versolaikkuindeksi, VLI) selvitettiin Weinhodin ym. (1982) kehittämällä 
menetelmällä, jossa arvioidaan varsikohtaisesti, kuinka iso osa varren maanalaisesta osasta on versolaikun peitossa. Kenttäkoe suoritettiin sekä luomu- että monokulttuurilohkolla osaruutumenetelmällä neljänä kerranteena, lajike pääruuduissa ja siemen osaruuduissa.

\section{Tulokset ja tulosten tarkastelu}

Siemenen seittirupisuuden kasvaessa myös versolaikun määrä kasvoi ja varsi- ja mukulaluku, sadon määrä ja tärkkelyspitoisuus laski (Taulukko 1). Voimakkaasti seittirupinen siemen (tasot 3 ja 4) laski satotasoa jopa $30 \%$. Siemenen seittirupisuuden lisääntyessä myöskin sadon laatu heikkeni. Erityisesti epämuotoisten ja vihertyneiden määrä kasvoi. Myöskin mukulan keskeltä ruskolaikkuisten ja onttojen mukuloiden osuus kasvoi lievästi. Seittirupisesta erästä valikoitu seittiruveton siemen (taso 0 ) ei eronnut missään suhteessa terveestä kontrollista. Tästä voi päätellä, että näkyvän seittiruven välttäminen siemenperunassa oli riittävä toimenpide taudin välttämiseksi. Toisaalta lieväkin siemenen seittirupisuus (taso 1) oli riittävä aiheuttamaan ongelmia sadonmuodostukselle ja laadulle (Taulukko 1).

Siemenen seittirupisuuden vaikutus oli enimmäkseen riippumaton viljelymenetelmästä (Taulukko 2, siemen $\mathrm{x}$ viljelymenetelmä -yhdysvaikutukset). Kuitenkin, siemenen seittirupisuuden lisääntyminen lisäsi sadon seittirupisuutta vain luomuviljelyssä (Kuvio 2). Myöskin epämuotoisten mukuloiden määrä kasvoi enemmän luomussa kuin tavanomaisessa viljelyssä, kun siemenen seittirupisuus kasvoi (Taulukko 2).

Taulukko 1. Siemenen seittirupisuuden vaikutus perunan kasvuun ja terveyteen ja sadon määrään ja laatuun

\begin{tabular}{|c|c|c|c|c|c|c|c|c|c|c|}
\hline & \multicolumn{3}{|c|}{ VLI Varsi- Mukula- } & \multicolumn{2}{|c|}{ Sato Tärkki } & \multicolumn{4}{|c|}{ Seitti- Vihert. Epämuot. Ruskeaa } & \multirow{3}{*}{$\begin{array}{r}\text { Ontot } \\
\% \\
\end{array}$} \\
\hline & & luku & luku & & & rupi- & & & kesk. & \\
\hline & & & & $\mathrm{tn} / \mathrm{ha}$ & & ndeksi & $\%$ & $\%$ & $\%$ & \\
\hline Kontrolli & 1.2 & 4.7 & 10.6 & 28.2 & 14.5 & 0.4 & 1.7 & 3.1 & 22.5 & 0.4 \\
\hline 0 & 1.8 & 4.4 & 10.5 & 28.3 & 14.5 & 0.4 & 2.0 & 3.5 & 24.0 & 0.4 \\
\hline 1 & 5.6 & 4.1 & 9.4 & 25.4 & 14.2 & 0.7 & 2.2 & 3.6 & 23.4 & 1.1 \\
\hline 2 & 13.1 & 3.9 & 8.3 & 23.0 & 13.8 & 0.9 & 2.4 & 7.6 & 23.1 & 0.9 \\
\hline 3 & 16.5 & 3.7 & 7.8 & 20.6 & 13.6 & 1.2 & 3.5 & 9.2 & 25.1 & 2.4 \\
\hline 4 & 17.4 & 3.3 & 7.4 & 20.2 & 13.4 & 1.2 & 2.9 & 9.6 & 24.9 & 3.2 \\
\hline$F$-testi & $* * *$ & $* * *$ & $* * *$ & $* * *$ & $* * *$ & $* * *$ & $*$ & $* * *$ & ns & $* * *$ \\
\hline PME & 3.60 & 0.54 & 0.67 & 2.15 & 0.41 & 0.17 & 1.24 & 2.18 & - & 1.4 \\
\hline
\end{tabular}

$* * * \mathrm{p}<0.001, * \mathrm{p}<0.05, \mathrm{~ns}=$ ei merkitsevä

Versolaikun määrä (VLI) oli keskimäärin hieman pienempi luomussa kuin tavanomaisessa viljelyssä (Taulukko 2). Koska perunarutto tuhosi molempina tutkimusvuosina luomukokeen varret hyvin aikaisin, tämän luomuviljelyn hieman lievemmän tartuntatason mahdollisia positiivisia vaikutuksia sadon määrään ei pystytty mittamaan. Päinvastoin, ruttoepidemian seurauksena luomun keskimääräinen satotaso jäi vaatimattomaksi ja tärkkelyspitoisuus matalaksi. Myöskin luomukokeen keskimääräinen mukulaluku jäi pieneksi, ainakin osaksi siksi, että osa hyvin pienikokoisista mukuloista jäi nostossa maahan. Vaikka luomun mukulat jäivät pienikokoisiksi, niissä oli kuitenkin keskimäärin tavanomaista viljelyä enemmän epämuotoisuutta, onttoutta ja ruskeaa keskellä. Myöskin luomusadon keskimääräinen seittirupisuus oli selvästi tavanomaista viljelyä voimakkaampaa. (Taulukko 2).

Lajikkeet reagoivat hieman eri tavoin siemenperäiseen seittitartuntaan (Taulukko 2, siemen x lajike yhdysvaikutus). Se näkyi lähinnä siten, että Van Goghin satotaso laski hieman Saturnaa voimaakkaammin ja sadon seittirupisuus ja onttous lisääntyi hieman Saturnaa enemmän siemenen seittirupisuuden kasvaessa. Selvät lajike-erot kasvussa ja sadon laadussa johtuivat muutoin eroista lajikkeiden luontaisissa ominaisuuksissa. 
Taulukko 2. Viljelymenetelmän ja lajikkeen vaikutus perunan kasvuun ja terveyteen ja sadon määrään ja laatuun

\begin{tabular}{|c|c|c|c|c|c|c|c|c|c|c|}
\hline & \multirow{2}{*}{\multicolumn{3}{|c|}{$\begin{array}{l}\text { VLI Varsi-Mukula- } \\
\text { luku luku }\end{array}$}} & \multicolumn{2}{|c|}{ Sato Tärkki } & $\begin{array}{l}\text { Seitti- } \\
\text { rupi- }\end{array}$ & \multicolumn{3}{|c|}{$\begin{array}{r}\text { Vihert. Epämuot. Ruskeaa } \\
\text { kesk. }\end{array}$} & \multirow{2}{*}{$\begin{array}{r}\text { Ontot } \\
\%\end{array}$} \\
\hline & & & & $\mathrm{tn} / \mathrm{ha}$ & $\%$ & Ideksi & $\%$ & $\%$ & $\%$ & \\
\hline Monokulttuuri & 10.5 & 4.0 & 11.8 & 37.9 & 16.0 & 0.4 & 3.0 & 3.8 & 15.1 & 0.6 \\
\hline Luomu & 8.0 & 4.1 & 6.9 & 14.1 & 12.5 & 1.1 & 2.1 & 7.9 & 30.4 & 1.9 \\
\hline$F$-testi & $*$ & $\mathrm{~ns}$ & $* * *$ & $* * *$ & $* * *$ & $* * *$ & ns & $* * *$ & $* * *$ & $*$ \\
\hline Van Gogh & 8.7 & 2.7 & 7.9 & 26.3 & 13.0 & 0.9 & 2.6 & 4.2 & 4.0 & 2.5 \\
\hline Saturna & 9.9 & 5.4 & 10.1 & 22.2 & 14.9 & 0.7 & 2.3 & 8.0 & 43.7 & 0.2 \\
\hline$F$-testi & ns & $* * *$ & $* *$ & $*$ & $* * *$ & $* * *$ & $\mathrm{~ns}$ & $* * *$ & $* * *$ & $* *$ \\
\hline $\begin{array}{l}F \text {-testi yhdysvaikutul } \\
\text { siemen x viljelytapa }\end{array}$ & $\begin{array}{r}\text { sille } \\
\text { ns }\end{array}$ & ns & ns & ns & ns & $* * *$ & ns & $* * *$ & ns & $\mathrm{ns}$ \\
\hline siemen x lajike & ns & ns & ns & $*$ & ns & $* *$ & ns & ns & ns & $* * *$ \\
\hline
\end{tabular}

$* * * \mathrm{p}<0.001, * * \mathrm{p}<0.01, * \mathrm{p}<0.05, \mathrm{~ns}=$ ei merkitsevä

Kuvio 2. Siemenen seittirupisuuden vaikutus sadon seittirupisuuteen (jana=keskihajonta)

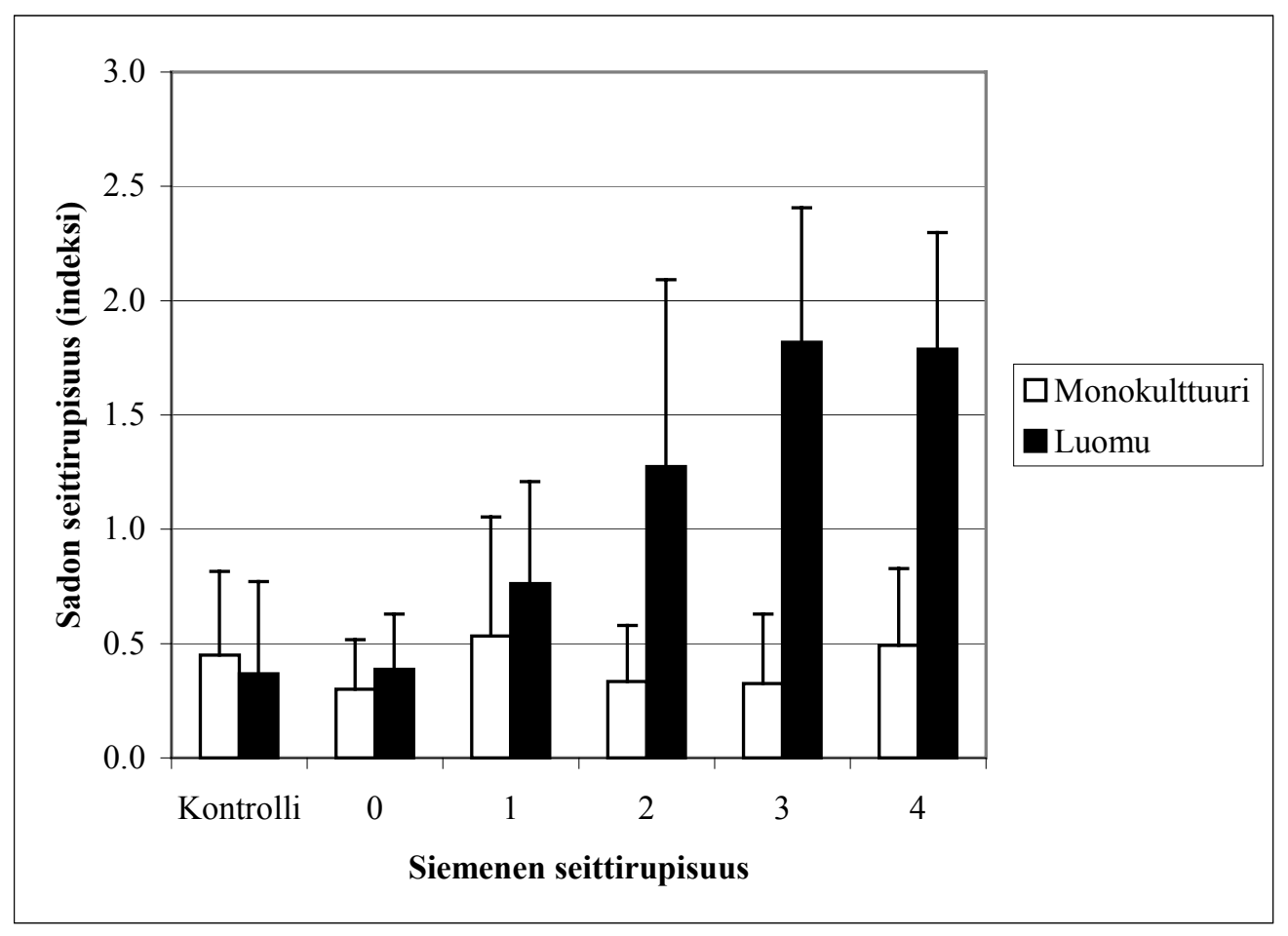

\section{Johtopäätökset}

Yhteenvetona voimme todeta, että viljelytavasta riippumatta nimen omaan siemenen seittiruvettomuudella on keskeinen merkitys seitin torjunnassa. Vähäinenkin määrä seittirupea siemenperunassa voi aiheuttaa merkittävää vahinkoa.

\section{Kirjallisuus}

Dijst, G. 1985. Investigations on the effect of haulm destruction and additional root cutting on black scurf on potato tubers. Neth. J. P1. Path. 91:153-162.

Weinhold, A. R., Bowman, T. \& Hall, D. H. 1982. Rhizoctonia disease of potato: Effect on yield and control bv seed tuber treatment. Pl. Dis. 66: 815-818. 